\title{
UCLA
}

Mester

Title

Prefacio

Permalink

https://escholarship.org/uc/item/3n49g8nz

Journal

Mester, 49(1)

Author

Rumrrill, Roger

Publication Date

2020

DOI

10.5070/M3491051390

Copyright Information

Copyright 2020 by the author(s). All rights reserved unless otherwise indicated. Contact the author(s) for any necessary permissions. Learn more at https://escholarship.org/terms

Peer reviewed 


\section{Ecosocial Human Rights}





\title{
Prefacio
}

\author{
Róger Rumrrill
}

\section{La Pandemia del Coronavirus y Otro Modelo de Vida}

A lo largo de la historia de la humanidad, se han desatado guerras, han ocurrido catástrofes algunas veces naturales y también plagas y pestes que han cobrado y originado millones de muertes en diferentes zonas del planeta.

Pero la pregunta que aquí nos formulamos es por qué ahora, en la segunda década del siglo XXI, un virus invisible a simple vista está ocasionando una crisis de dimensiones globales que, sin duda, hará cambiar el curso de la historia humana.

Hay muchas respuestas pero la primera es que ahora el enemigo letal e invisible ha extendido la muerte a todo el mundo de uno a otro extremo del planeta Tierra y la sociedad humana ha entrado en pánico.

La segunda respuesta es porque todo el sistema-mundo, como escribió el filósofo Immanuel Wallerstein, estaba caminando al borde de una profunda crisis estructural. El coronavirus ha sido el detonante que ha puesto a prueba todo el castillo de arena que el hombre ha construido.

Nunca más la sociedad humana volverá a ser la misma que antes de la pandemia, dicen los académicos, los científicos, los filósofos. Nunca más debemos volver a "la normalidad", porque la normalidad es un sistema económico injusto y asimétrico, que ha hecho posible que el 1 por ciento de ricos en un planeta que tiene 7 mil millones de habitantes, concentren y disfruten de más del 90 por ciento de la riqueza mundial.

Nunca más hay que volver al mismo sistema. Porque este sistema ha sido y sigue siendo una máquina trituradora de la Madre Naturaleza. Porque como expresa el filósofo italiano Massino Cacciari, ninguna especie ha acelerado el proceso de su propia extinción como la especie humana que, señala el filósofo, se parece a los dinosaurios, esas enormes bestias que arrasaron su propio hábitat comiendo toneladas de materia prima cada día hasta extinguirlas y con la desaparición de los alimentos se extinguieron ellos también. 
"Los hombres somos dinosaurios de la inteligencia, de la mente y ninguna especie ha dominado el planeta como nosotros y los dinosaurios", reflexiona el filósofo.

\section{La Desacralización de la Madre Naturaleza}

Paradójicamente ha sido la propia ciencia que ha contribuido, muy tempranamente en la historia, con esta relación incestuosa y destructiva con la Madre Naturaleza. La naturaleza, la Madre Naturaleza, sacralizada por las cosmovisiones y cosmologías de los pueblos indígenas de Abya Yala, el nombre indígena del continente americano, terminó por ser desacralizada por el racionalismo cartesiano y el cientificismo de Francis Bacon (1562-1626), considerado el padre de la ciencia moderna y para quien el conocimiento científico y sus instrumentos "no ejercen meramente una gentil inducción sobre el curso de la naturaleza; tiene el poder de conquistarla y subyugarla, de commoverla hasta sus cimientos".

Con este pensamiento, con la fe moderna en la ciencia y en la creencia ciega en la teología del mercado, la naturaleza se transformó en materia prima y los seres humanos en "recursos humanos calificados”. Lo que le llevó a Robert Solow, el más destacado representante de la macroeconomía neokeynesiana a afirmar: "La vieja preocupación sobre el agotamiento de los recursos naturales no descansa más en ninguna base teórica firme".

A tono con esta idolatría cientificista, el ex presidente George W. Bush en su informe sobre el Estado de la Unión dijo que el calentamiento climático y sus consecuencias serían solucionados con los instrumentos de la tecnología y los milagros de la ciencia. Pero el actual presidente de EEUU, Donald Trump se ha ido mucho más lejos todavía: no cree en el calentamiento climático. Es un negacionista radical.

En síntesis, para el pensamiento científico occidental, el concepto de naturaleza y de realidad es, fundamentalmente, material, o sea, la materia es la base de lo real. En esta realidad existe un mundo único, unificado, regido por leyes físicas y químicas, únicas y válidas para todos los ámbitos. Las leyes de la lógica aristotélica y clásica. Mundos en la categoría de naturaleza, opuestos a los de cultura y sociedad.

Por el contrario, para el pensamiento, los saberes, las prácticas, las cosmovisiones y cosmologías de los pueblos indígenas y originarios de la Amazonía, el Chaco y los bosques tropicales de América Latina y el Caribe, la realidad tiene aspectos materiales y no materiales, visibles y 
no visibles, ordinarias y extraordinarias. Para este pensamiento, existe un único cosmos. Pero este cosmos es una unidad en la multiplicidad. Es la unidad de lo diverso. Este cosmos está compuesto por diversos mundos ubicados en espacios y planos espaciales diferentes: el mundo del bosque, de los ríos y de los lagos. En este mundo, naturaleza y cultura son concebidas como partes.

En estos mundos no visibles habitan las esencias primordiales de las cosas: las madres de la naturaleza, los genios de las plantas, de los minerales y de los animales. En tiempos primordiales, todos eran gente. Pero este cosmos primordial, indiviso, en un momento de la historia se dividió y fraccionó. Los movimientos milenaristas y mesiánicos indígenas que se han sucedido a lo largo de la historia, como el de Juan Santos Atahualpa, en el Perú del siglo XVIII, estaban a la búsqueda de la recomposición y la unidad de este mundo.

El panteísmo y animismo indígenas, que es un retorno a la creencia original de que el hombre está integrado a la naturaleza, como un todo, es hoy, en la segunda década del siglo XXI y en el curso de una crisis ambiental planetaria que es el cambio climático, que algunos científicos columbran como irreversible y apocalíptica, uno de los mayores y mejores paradigmas ambientalistas y conservacionistas y un nuevo modelo de sociedad y de relación con la naturaleza.

Porque mientras que en la sociedad capitalista neoliberal el ser humano vive sólo para consumir, en el modelo de sociedad indígena el hombre y la mujer consumen sólo para vivir.

Después de todo el mismo desarrollo y evolución de la ciencia nos conducen a los maravillosos mecanismos de funcionamiento de la naturaleza y la vida. Porque la ciencia moderna nació con Galileo en el siglo XVII y un siglo después se formularon y establecieron sus principios teóricos y sus principios prácticos se vieron en el siglo XIX con la revolución industrial. Por eso, el siglo XIX fue el siglo de la química y la mecánica, el siglo XX el siglo de la física y el siglo XXI el siglo de la biología y la revelación del misterio de la vida.

Los filósofos de la postmodernidad, Leonardo Boff, Humberto Maturana, Francois Lyotard y Félix Guattary lo saben y por eso se han atrevido a sostener que la única posibilidad de que el hombre sobreviva en el planeta Tierra es rearticular su relación con la Madre Naturaleza, volviendo a ser parte esencial de ella, asumiendo una condición animista y panteísta, en una relación cosmocéntrica son su entorno biofísico y espiritual. 
Si el advenimiento de la modernidad sólo fue posible luego de los cambios y transformaciones de la Edad Media, paralizada durante diez largos siglos por la asunción dogmática de la fe y la razón, las sociedades indígenas de Abya Yala, desde su pensamiento, cosmovisiones y cosmologías están poniendo en cuestión todos los extravíos y excesos de la supuesta modernidad de la globalización, de la economía neoliberal, del extractivismo, la cultura y la política eurocéntrica y sobre todo de su voluptuosa e insaciable capacidad destructora de la Madre Naturaleza.

Lake Elsinore, California, EEUU, setiembre de 2020. 